\title{
Novel Data on the Ecology of Cochranella mache (Anura: Centrolenidae) and the Importance of Protected Areas for This Critically Endangered Glassfrog in the Neotropics
}

\author{
H. Mauricio Ortega-Andrade ${ }^{1,2,3 *}$, Octavio Rojas-Soto ${ }^{1}$, Christian Paucar ${ }^{4}$ \\ 1 Instituto de Ecología A.C., Red de Biología Evolutiva, Xalapa, México, 2 FundaciónEcoCiencia, Programa para la Conservación de Especies Amenazadas de Extinción en \\ Ecuador, Quito, Ecuador, 3 Museo Ecuatoriano de Ciencias Naturales, Sección de Vertebrados, División de Herpetología, Quito, Ecuador, 4 Universidad Central del Ecuador,
} Escuela de Biología y Química, Quito, Ecuador

\begin{abstract}
We studied a population of the endangered glassfrog, Cochranella mache, at Bilsa Biological Station, northwestern Ecuador, from 2008 and 2009. We present information on annual abundance patterns, behavioral ecology, habitat use and a species distribution model performed with MaxEnt. We evaluate the importance of the National System of Protected Areas (SNAP) in Colombia and Ecuador, under scenarios of climate change and habitat loss. We predicted a restricted environmental suitability area from $48,509 \mathrm{Km}^{2}$ to $65,147 \mathrm{Km}^{2}$ along western Ecuador and adjacent Colombia; $\sim 8 \%$ of the potential distribution occurs within SNAP. We examined four aspects of $C$. mache ecology: (1) ecological data suggests a strong correlation between relative abundance and rainfall, with a high probability to observe frogs through rainy months (February-May); (2) habitat use and the species distribution model suggest that this canopy dweller is restricted to small streams and rivulets in primary and old secondary forest in evergreen lowland and piedmont forest of western Ecuador, with predictions of suitability areas in adjacent southern Colombia; (3) the SNAP of Colombia and Ecuador harbor a minimum portion of the predicted model of distribution $(<10 \%)$; and (4) synergetic effects of habitat loss and climate change reduces in about $95 \%$ the suitability areas for this endangered frog along its distributional range in Protected Areas. The resulting model allows the recognition of areas to undertake conservation efforts and plan future field surveys, as well as forecasting regions with high probability of $C$. mache occurrence in western Ecuador and southern Colombia. Further research is required to assess population tendencies, habitat fragmentation and target survey zones to accelerate the discovery of unknown populations in unexplored areas with high probability of suitability. We recommend that Cochranella mache must be re-categorized as "Critically Endangered" species in national and global status, according with criteria and sub-criteria A4, B1ab(i,ii,iii,iv),E.
\end{abstract}

Citation: Ortega-Andrade HM, Rojas-Soto O, Paucar C (2013) Novel Data on the Ecology of Cochranella mache (Anura: Centrolenidae) and the Importance of Protected Areas for This Critically Endangered Glassfrog in the Neotropics. PLoS ONE 8(12): e81837. doi:10.1371/journal.pone.0081837

Editor: Christopher Joseph Salice, Texas Tech University, United States of America

Received February 2, 2013; Accepted October 26, 2013; Published December 5, 2013

Copyright: @ 2013 Ortega-Andrade et al. This is an open-access article distributed under the terms of the Creative Commons Attribution License, which permits unrestricted use, distribution, and reproduction in any medium, provided the original author and source are credited.

Funding: H.M.O-A received funding for this project by a grant from Programa de Becas de Investigación para la Conservación (PBIC) sponsored by Fundación Ecociencia and Conservation International-Ecuador in 2007, and Fundación Jatun Sacha provided free room, board and access to facilities for the field work at the Bilsa Biological Station. HMO-A Doctorate research is currently being financially supported by two fellowship grants from Consejo Nacional de Ciencia y Tecnología (CONACyT, Mexico) and Secretaría Nacional de Educación Superior, Ciencia, Tecnología e Innovación (SENESCYT, Ecuador). The funders had no role in study design, data collection and analysis, decision to publish, or preparation of the manuscript.

Competing Interests: The authors have declared that no competing interest exist.

*E-mail: biomauro@hotmail.com

\section{Introduction}

Amphibians are quickly declining worldwide and disappearing, especially in the tropical Andes [1-5]. This is true for Ecuador and Colombia, with $\sim 30 \%$ of species considered threatened by extinction, and over $18 \%$ considered as data deficient for categorization [2]. Changes in forest coverage have favored increment of habitat temperature, increase in the length of the rainy seasons, decrease of ground humidity and increase in the variability of inter-year rains in tropical forest of western Ecuador [6]. These variations can severely affect tropical amphibian communities [7]. Moreover, synergies on environmental factors and anthropogenic activities seem to have favored the presence of emerging diseases in amphibians, expansions of invader species and an accelerated process of deforestation, fragmentation and habitat loss in tropical forest [3,5,8-13]. Red lists of taxa and threatened categories proposed by IUCN [2,14,15] are mainly evaluated on the basis of quantitative and qualitative-observed, inferred or suspected - demographic and ecological data, related to population sizes, distribution and occupancy of areas, regional threats and probabilities of extinction. However, it is necessary to assess those species with cryptic behavior, restricted distributions that are difficult to sample, limitations on the availability of localities records, and few data on the impact of habitat loss and relative population declines.

Cochranella mache Guayasamin \& Bonaccorso, is an endemic species from northwestern Ecuador distributed on the tropical lowland forest and eastern slopes of Cordillera Mache-Chindul (=Montañas de Mache-Chindul), a rather isolated mountain range in the northern portion of Cordillera de la Costa, and western slopes of the Cordillera de los Andes. Although the known range of C. mache is encompassed by protected areas, it is globally listed as Critically Endangered, because its extent of occurrence is 
considered to be less than $5000 \mathrm{~km}^{2}$ in five locations, where habitat undergoes constant extent declines, and its natural history remains poorly understood [16]. However, Ron et al. [17] considered this species nationally categorized as Data Deficient.

A wide range of methods has been used to evaluate the ecological niches and potential geographic distribution of species based on quantitative presence data, to infer species environmental requirements, predict distributions areas, and confront current and future biodiversity threats [13,18-22]. Models generated with small sample sizes should be used to identifying, within a statistical and ecological context, regions that have similar environmental conditions which delimiting the potential distributional range for species. Thus, models based only in abiotic conditions ignoring other aspects of the evolutionary history of the species (biotic factors, vagility, local extinctions and the capacity of populations to adapt to new conditions) could result in an erroneous model for the geographic distribution of species [23,24].

Despite the difficulty of obtaining detailed species' inventories, biologists increasingly rely on distribution models to perform conservation strategies [22,24-28]. However, there is a critical problem about threatened species in conservation biology: the need to know the essential environmental conditions which are occupied in a context of fundamental ecological niche theory [23,29-31], based in poor information and a quite limited number of occurrence records [22].

To deal with these ecological aspects of this uncommon and endangered frog, the main goals of this study were: (1) to evaluate the influence of rainfall in the annual abundance pattern, (2) to provide new data on natural history and habitat use of $C$. mache at Bilsa Biological Station; and (3) to evaluate the importance for conservation of C. mache of National System of Protected Areas in Ecuador and adjacent Colombia, over a predicted model of distribution for the species in scenarios of climate change and habitat loss; all in order to provide solid current bases to assess its risk categorization and plan its further conservation.

\section{Methods}

\section{Ethics statement}

To conduct this study, we obtained the research permit $\mathrm{N}^{\circ} 002$ from the Governmental Authority (the Ministerio del Ambiente del Ecuador) approved by Ing. J. Trujillo, to work in localities along Esmeralda's province, northwestern Ecuador. The Bilsa Biological Station is a private reserve owned and managed by the Fundación Jatun Sacha; permits were granted in 2007 by the Executive Director, Dr. M. Asanza. The microhabitats where $C$. mache is known to inhabit were carefully surveyed at night time (2000 h-2300 h) by direct inspection. Manipulation of animals in the field was minimal in all cases. We measured each individual with a digital caliper (0.05 $\mathrm{mm}$ accuracy), recorded their vocalizations with an Olympus Digital voice Recorder VN-4100 and photographed them with a Samsung S85 digital camera. After we documented these ecological data, individuals were returned to the same site where they were found. During our study we did not make scientific collections in field, but additional specimens were found housed in the Museo Ecuatoriano de Ciencias Naturales (MECN, Quito, Ecuador), Fundación Herpetológica Gustavo Orcés (FHGO, Quito, Ecuador), and Museo de Zoología, (QGAZ, Quito, Ecuador).

\section{Study region and field surveys}

Western Ecuador exhibits substantial environmental gradients, with diverse climates and complex topography due to the presence of the Mache-Chindul mountain range and its closeness to the
Andes mountain range. These areas are mainly covered by Foothill evergreen forests and lowland evergreen forests, as part of the Western Ecuadorian Biogeographic Province [32]. In this region, the dry season occurs from July to December and the wet season from January to June, with an annual average rainfall of 1500-2000 $\mathrm{mm}$ [33]. In order to find the species in the field, we decided to monitor populations in Dos Bocas, the type locality of C. mache, and Piscinas, Rompe-frente and Río Duchas, three other rivulets at Bilsa Biological Station BBS $\left(\mathrm{N}^{\circ} 0.359170\right.$, $\mathrm{W}^{\circ} 79.700560$; altitudinal range from $300-750 \mathrm{~m}$ a.s.l.), in Mache-Chindul Mountain range, northwestern Ecuador. These rivulets were previously pre-selected by direct inspection by H.M.O-A in 2006, based on ease of accession and local facilities to do field work. Three of them (Piscinas, Rompe-frente, Dos Bocas) are rivulets with primary and well-preserved forests, but Río Duchas is covered mainly by old secondary forest. The surrounding areas have been largely deforested for small-scale agriculture, although several fragments of primary and secondary forests remain in the Bilsa Biological Station [34]. These sites are located in a range of $1000-2000 \mathrm{~m}$ from each other, therefore are considered statistically as nested samples in regard to avoid random effects or pseudoreplication.

Field surveys were made through five sampling sessions during 2008 (13-25April, 9-17 May, 11-18 October) and 2009 (20-29 January and 14-23 April). Each day, the microhabitats where $C$. mache is known to inhabit were carefully surveyed at night $(2000 \mathrm{~h}-$ $2300 \mathrm{~h}$ ), in a randomly selected rivulet. Sampling effort per day was 6 person-hours ( 2 people $\mathrm{X} 3$ hours) and the cumulative sampling effort for the study was 300 person-hours 6 person hours $\mathrm{X} 50$ days of surveys). We registered data traits on each frog encountered as follows: snout-vent length (SVL, mm), sex (direct inspection of vocal sac, gravid females), reproduction behavior (mating and egg deposition), and activity. To assess the use of microhabitat, we recorded the substrates on which each specimen was observed, and we assigned them to one of the following types of vertical forest stratification: understory $(<2 \mathrm{~m}$ above ground), midstory $(2-10 \mathrm{~m})$, and canopy $(>10 \mathrm{~m})$. In spite of our effort, the canopy strata may be under-sampled due by sampling limitations. To assess the relation between relative abundances $(\mathrm{RA}=$ \# frogs observed/3 hours) and daily rainfall ( $\mathrm{mm})$ through samplings, we performed a Non-parametric Correlation and generated a Maximum Likelihood Linear Regression Model using R software (http://www.r-project.org/). Differences among relative abundances of individuals per rivulet and vegetation type were tested with Generalized Linear Models (GLM), with Poisson distribution, and a $P$-value was calculated using $\mathrm{R}$ software. Differences on snout-vent length between males and females were compared with a non-parametric Mann-Whitney test (U'), whereas the preferences in vertical forests stratification were tested with a Chisquared test $\left(\mathrm{X}^{2}\right)$, developed in PAST 1.86b software [35].

The call described herein for C. mache was recorded using an Olympus Digital voice Recorder VN-4100. Distance between recorder and frog was $\sim 2 \mathrm{~m}$. Five parameters were measured to describe the structure of each call, as follows [36,37]: (1) Call length $=$ time from beginning to end of one call, measured from waveform in milliseconds; (2) dominant frequency $=$ frequency in call containing the greatest amount of energy determined from the entire call; (3) call rise time = time from beginning of the call to point of maximum amplitude; (4) interval between calls $=$ time from ending of a call and beginning of next call; and (5) call rate $=$ total number of calls-1/time from beginning of first call to beginning of last call, all relativized to 60 seconds. Measurement of fundamental frequency follows the technique used by Hutter and Guayasamin [38]. A note is considered herein as an element with 
similar acoustic structure, whereas a pulse is the repetition of the calling note along the repertory. The sonogram was produced and analyzed using the program Raven Pro 1.5. After a preliminary review of the original sound spectrogram, we have applied a filter band-pass between 4300 and $7000 \mathrm{~Hz}$ in order to reduce noise and maximize the measurement of acoustic parameters. The dominance frequency was calculated with a size of 1500 samples in the spectrogram window. Recordings are deposited in the Sound Archive of the Museo Ecuatoriano de Ciencias Naturales and Museo de Zoología of Pontificia Universidad Católica del Ecuador and will be available at Amphibia Web Ecuador (http://zoologia. puce.edu.ec/vertebrados/anfibios/).

\section{Species Distribution Model}

Our database gathers data from the seven known localities reported by different authors $[16,34,39,40]$, and is shown in Table 1. Geographic coordinates are provided in decimal degrees, based on the WGS 84 datum. Each locality was carefully geo-positioned (lat-long coordinates) to correct the geographic coordinates of imprecise localities and to eliminate any inconsistencies or duplicates. The corroboration was based on the revision of databases and specimens housed in the Fundación Herpetológica Gustavo Orcés (FHGO); Museo Ecuatoriano de Ciencias Naturales (DHMECN); and Museo de Zoología, Pontificia Universidad Católica del Ecuador (QCAZ), Quito, Ecuador.

We modeled the habitat suitability for C. mache, with the MaxEnt Software version 3.3.3a. [20,41,42]. MaxEnt estimates the probability of distribution that has maximum entropy applying the following principle: the expected value for each feature (i.e. climatic variables) must equal the empirical average value for points relating to known presence. The algorithm performs a certain number of iterations until reaching a convergence limit. The final map represents a favorability rating ranging from 0 (unsuitable) to 1 (perfectly adequate) [30]. The program uses two input resources: localities of the species record (presence-only data) and digital layers of the environmental conditions of a given area. For a first explorative model, we used the localities dataset described above, in combination with 19 climate layers from the WorldClim project [43]. In a second modeling exercise, we generated the species distribution using only the environmental variables that were relevant according to the Jackniffe test, calculated by Maxent [44]. This allowed us to reduce over-fitting on the distribution models generated for this species [45]. Resolution grid cell size, or pixel size, was 0.0083 degrees, which correspond nominally $\sim 1 \mathrm{~km}^{2}$ in each raster.

Table 1. Localities of occurrence for Cochranella mache in northwestern Ecuador.

\begin{tabular}{|c|c|c|c|}
\hline Locality & Latitude & Longitude & m.a.s.I. \\
\hline 3 km NW from Quinindé & $\mathrm{N}^{\circ} 0.350000$ & $W^{\circ} 79.483330$ & 150 \\
\hline Alto Tambo, Carolina River & $N^{\circ} 0.912748$ & $W^{\circ} 78.618827$ & 453 \\
\hline Bilsa Biogical Station & $\mathrm{N}^{\circ} 0.359170$ & $W^{\circ} 79.700560$ & 800 \\
\hline Canandé Biological Reserve & $N^{\circ} 0.447720$ & $W^{\circ} 79.148080$ & 270 \\
\hline Comunidad San Salvador* & $N^{\circ} 0.496710$ & $W^{\circ} 79.852980$ & 38 \\
\hline Hacienda Shangrilá* & $N^{\circ} 0.186300$ & $W^{\circ} 79.030190$ & 499 \\
\hline Monte Saíno, San Francisco del Cabo & $N^{\circ} 0.704560$ & $W^{\circ} 80.025330$ & 100 \\
\hline
\end{tabular}

To aid model validation and interpretation, it is usually desirable to distinguish 'suitable' from 'unsuitable' areas by setting a decision threshold above which model output is considered to be a prediction of the species presence. There is no set rule to set these thresholds because its selection depends on the data used or the objective of the map, and will vary from species to species [46]. Then, we followed the settings suggested by Pearson et al. [24] for small numbers of occurrence records, where multiple predictions (seven from our database) were made with one of the observed localities excluded in each case. For each prediction, two threshold decisions were applied (Minimum training presence and Fixed cumulative value of 20), and the ability to predict the excluded locality was tested. A $P$-value was then calculated for the overall model across the set of jackknife predictions using the script made by Pearson et al. [24].

The overall predictive model of distribution for the species was generated with all the localities from the database, 5000 iterations and specified to the program not to do clamping and not to extrapolate, in order to avoid artificial extrapolations on the extremes of the ecological variables. All other parameters were maintained as default settings in MaxEnt. The logistic format was used to obtain the values of habitat suitability (continuous probability from 0 to 1 ), and then converted to binary presenceabsence values. The results for both threshold values (MTP and T20) were represented by two distinct colored areas in the geographic space, whereas MTP is a sub-conjunct in T20.

To improve, accurate and validate the predicted distribution model of the species, we based our ecological criteria in classifications for Vegetation Formations [33], Terrestrial EcoRegions [47], and Biogegraphic Provinces [32] in northwestern South America. These criteria were used in combination because adding historical, evolutive and ecological factors into the model generated for delimitate the species distribution area. To assess the effect of deforestation, we used a representation of vegetation land cover included in two proposals of classification system for continental Ecuadorian and Colombian ecosystems [48,49]. In order to evaluate the effect of habitat loss, we only consider the category called "natural forests" from both classification systems, whereas "perturbed areas" include categories which represent urban areas, secondary forests, deforested areas, farming areas and pasture land for cattle raising. We also evaluate the importance of the National System of Protected Areas (SNAP, from Spanish) in Ecuador and Colombia comparing the species distribution area predicted by our $C$. mache model against the area currently included in the SNAP, using layers downloaded from ProtectedPlanet.net [50]. The presence extension range was created from a geometric convex hull polygon that resulted from the union of all points on verified localities. Using a polygon could underestimates the presence extension range of the species, especially since $C$. mache was recently described and additional localities of occurrence are expected to record. Anyway, we decide to apply this method because is one of the techniques commonly used to evaluate the extension range of occurrence for threatened species [51]. Spatial analyses and map algebra were developed with ArcMap 10 Software, whereas the convex hull polygon was calculated from Minimum Bounding Geometry routine in ArcTool Box [52].

\section{Species Distribution Model in Scenarios of Future Global Climate Change}

Albeit the potential problems associated with the use of global climate change scenarios at local scales [53], we find then useful as they show possible tendencies in future potential distribution of species, in this case Cochranella mache. For this study, we used General Circulation Models (GCMs) developed by the Canadian 
Centre for Climate Modeling Analysis (CGCMA) consisting in a coupled atmosphere-ocean GCM. Therefore, two (CGCMA-A2 and CCCMA-B2) of the four climatic scenarios established by the International Panel for Climate Change [IPCC, 54], were used. GCMs results were downloaded from the WorldClim website as digital layers and are based on the same 19 bioclimatic variables (http://www.ipcc-data.org/sres/cgcml_info.html) used to generate the species distribution model; all include atmospheric and oceanic components such as heat flux, wind stress, salinity, levels of greenhouse gasses, soil drainage and moisture, snow and ice temperature, snow depth, cloud water content, effective radius of cloud droplets, vegetation type, among others.

The climatic models used herein are in various ways the two more moderate scenarios, in a framework of social and environmental strategies based on local and regional organization, being more likely probable to occur in the future world, rather than international cooperation and social equity schemes. Both climatic scenarios were generated in recent years by the IPCG, considering the main forces that may determine future emissions, and describe dynamic changes occurring in different directions; from demographic to technological and economic aspects, as well as the existence of sinks and sources of greenhouse gasses, the development of alternative schemes for energy production and the occurrence of changes in land use. A detailed description of each model is available in the IPCG Special Report on Emission Scenarios [54]. To predict the persistence of Cochranella mache's ecological niche in a relatively close future, we decided to use the 2050 temporal horizon, since the species faces multiple conservation problems that may seriously threat its survival in the short term, and also because of the higher levels of uncertainty associated to more distant scenarios. Thus, we generated two maps representing the potential distribution of C. mache in 2050, under the GCM's Canadian CCCMa-A2 ("pessimistic") and CGCMa-B2 ("optimistic") climatic scenarios.

\section{Results}

\section{Abundance}

We recorded 129 individuals of C. mache at Bilsa Biological Station throughout 2008 and 2009 surveys (Fig. 1). The overall average of observed frogs during the rainy season was 3.2 individuals per sampling day, and none was recorded in the dry season (October). We found an annual increase rainfall pattern from January to April (range: 4224-6080 mm), and a constant rainfall pattern that stays below the average annual rainfall from May to December (range: $422-2727 \mathrm{~mm}$ ). We also found a significant correlation value $(\mathcal{N}=48, r=0.456 ; P<0.001)$ between daily rainfall and relative abundance, with increase of individuals observed from January to April (Fig. 2). The maximum likelihood linear model fits by the equation (Fig. 1B): Relative abundance (Frogs observed $/ 3$ hours per day) $=0.5823+0.00387$ ( rainfall); $21 \%$ of the total variation in the response of relative abundance is explained due variation in daily rainfall. We did not find differences in the observational probability of specimens among vegetation types $(P=0.57)$ or rivulets $(P=0.97)$ in Dos Bocas (0.33 ind./person-hour), Duchas (0.53 ind./person-hour), Piscinas (0.57 ind./person-hour) and Rompe-frente (0.61 ind./personhour).

\section{Natural history}

Cochranella mache (Fig. 1) is a medium sized frog, females $(\mathcal{N}=3$; $28-33.4 \mathrm{~mm} ; 31.4 \pm 2.96 \mathrm{~mm})$ are significantly larger than males (23-27.0 mm; 25.28 $\left.\pm 1.02 \mathrm{~mm} ; \quad \mathrm{U}^{\prime}=0 ; \quad P<0.001 ; \mathcal{N}=38\right)$. A gravid female (SVL $33.4 \mathrm{~mm}$ ) with about 30 eggs was observed

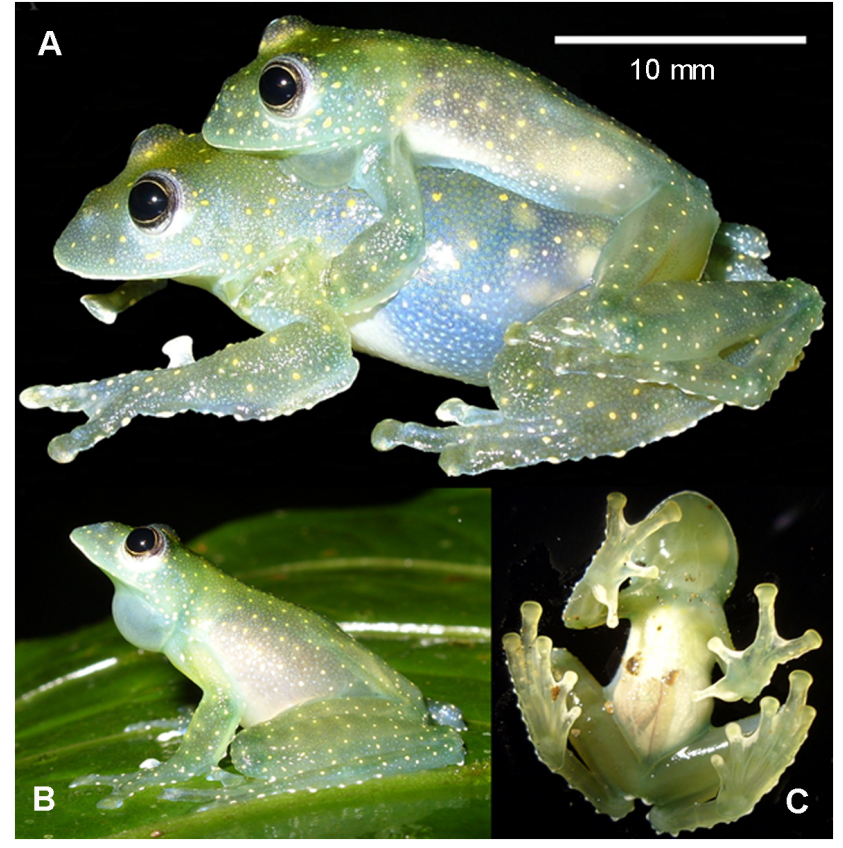

Figure 1. Cochranella mache. Amplectant pair captured on the April 22, 2009 Rompe-frente rivulet (A) and a calling male (SVL $=26.4 \mathrm{~mm}$, not collected) showing its profile and ventral views, photographed on the April 20, 2009 Rompe-frente rivulet, Bilsa Biological Station, northwestern Ecuador (B, C). Photographs by Christian Paucar. doi:10.1371/journal.pone.0081837.g001

on a leaf, $1.85 \mathrm{~m}$ above ground, the night of 22 April 2009 in Rompe-frente rivulet. That same night, we found a pair in axillar amplexus perched on a leaf, $1.5 \mathrm{~m}$ above the ground (Fig. 1A). Throughout the rainy season, males were common to hear, calling from the upper side of leaves or branches on trees and bushes. Frequently, chorus of 4 or 5 calling males were heard from the forest vegetation, within a relatively small area, spaced $\sim 10-\mathrm{m}$ apart, on overhanging vegetation along the rivulets (range: $0-6 \mathrm{~m}$, average \pm sd: $0.7 \pm 1 \mathrm{~m}$ ). About $80 \%$ of individuals were observed in the upper part of the forest (Fig. 3), with a notable preference of the midstory over the understory and canopy $\left(\mathrm{X}^{2}=76.3\right.$, $P<0.001)$.

We recorded two calls from a male at night (2254h) on May 9, 2008, in Rompe-frente rivulet (Fig. 1B). It was calling from the upper side of a dead Heliconia leaf, about $2.5 \mathrm{~m}$ above ground, horizontally separated from the rivulet's water by a distance in about $3 \mathrm{~m}$. Each call consists of two pulses, repeated $0.107-0.130$ second intervals, with duration of $0.038 \pm 0.008$ (0.029-0.049) seconds, and the call rise time in $0.013 \pm 0.007(0.002-0.021)$ seconds. The dominant frequency is $5410.2 \pm 17.9$ (5383.3-5426.4) Hz, being part of the fundamental frequency $(5139.5-6058.8 \mathrm{~Hz})$; the harmonics are not visible in the audiospectrogram. The rate is 1.46 calls per minute, repeated within $\sim 40.8$ seconds intervals (Fig. 4).

We also report predation behavior on C. mache from the colubrid snake Leptodeira septentrionalis arcorum Schmidt \& Walker (Colubridae), observed at $2249 \mathrm{~h}$ during the night on January 23, 2009, in Piscinas rivulet. The specimen (not sexed) was captured about $2.3 \mathrm{~m}$ above ground and eaten by the head (Fig. 5A). Besides, a female was observed captured by the neck by a Ctenus sp. spider (Aranae: Ctenidae), when the frog jumped to the water in Piscinas rivulet, on the night of January 23, 2009. The spider held the frog belly- up with legs outstretched (Fig. 5B). The frog, was struggling 
A
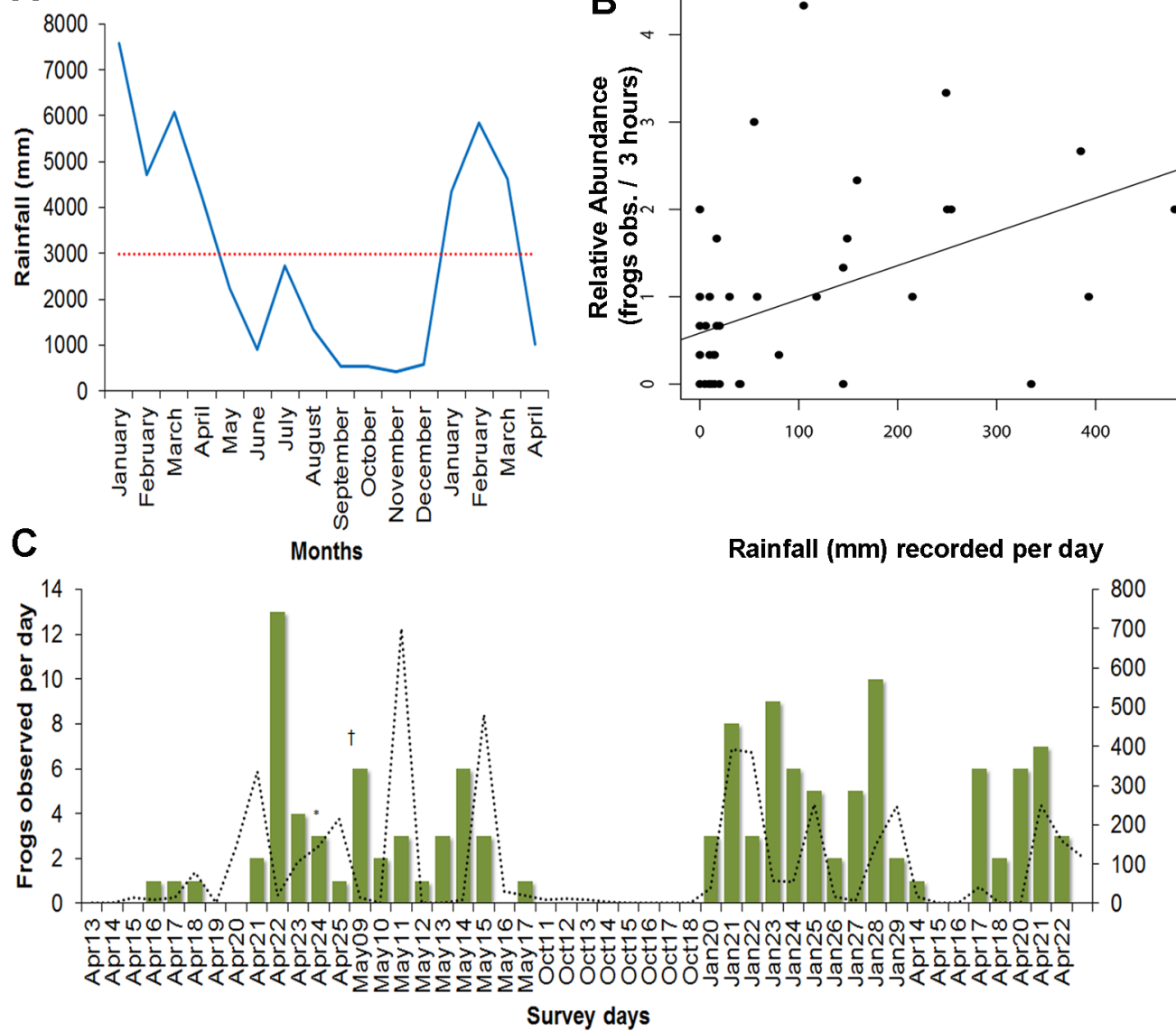

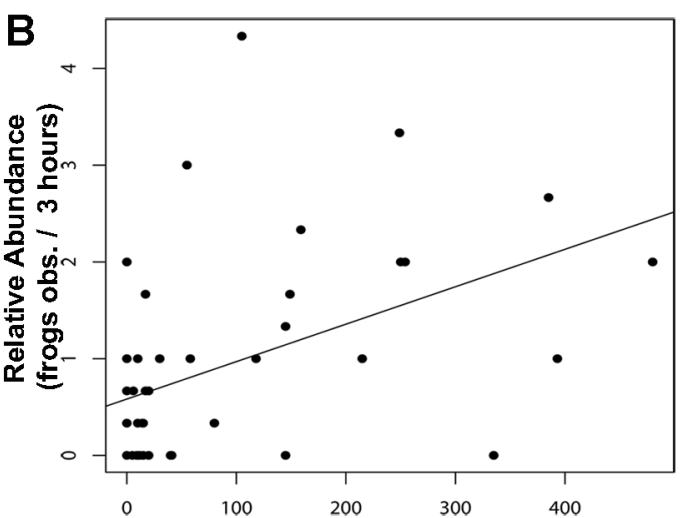

Rainfall (mm) recorded per day

Figure 2. Rainfall, abundance and records of reproductive specimens of Cochranella mache in Bilsa. (A) Rainfall records through years 2008-2009 in Mache-Chindul Mountain range. (B) Correlation $\left(N=48, r=0.456, r^{2}=0.21, P<0.001\right)$ and Maximum Likelihood Linear Regression Model $(\mathrm{Y}=0.5823+0.00387(\mathrm{X})$, between relative abundance (Individuals observed/3 hours per day) of C. mache and rainfall ( $\mathrm{mm}$ ). (C) Number of observed individuals of $C$. mache and daily rainfall $(\mathrm{mm})$ recorded through sampling days at Bilsa. The register of an amplectant pair $(*)$ and a specimen recorded for vocalization analysis $(\dagger)$ are shown in (C). doi:10.1371/journal.pone.0081837.g002

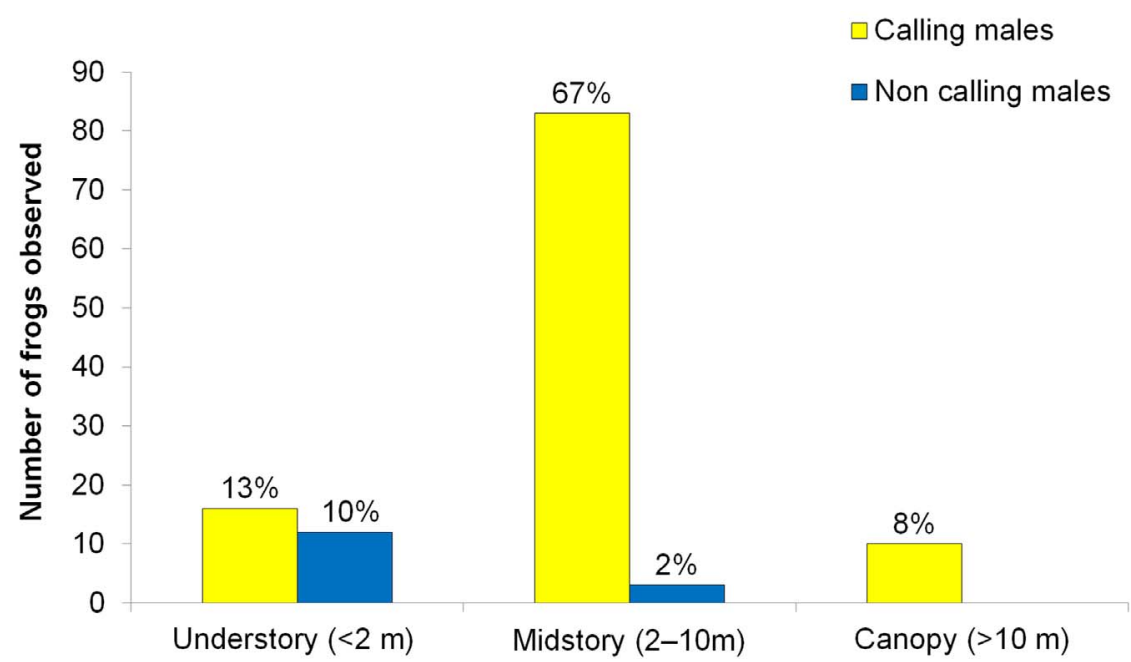

Figure 3. Vertical forest stratification use. Histogram of frequency (percentages) of males of $C$. mache, categorized by vertical forest stratification at Bilsa Biological Station, northwestern Ecuador.

doi:10.1371/journal.pone.0081837.g003 

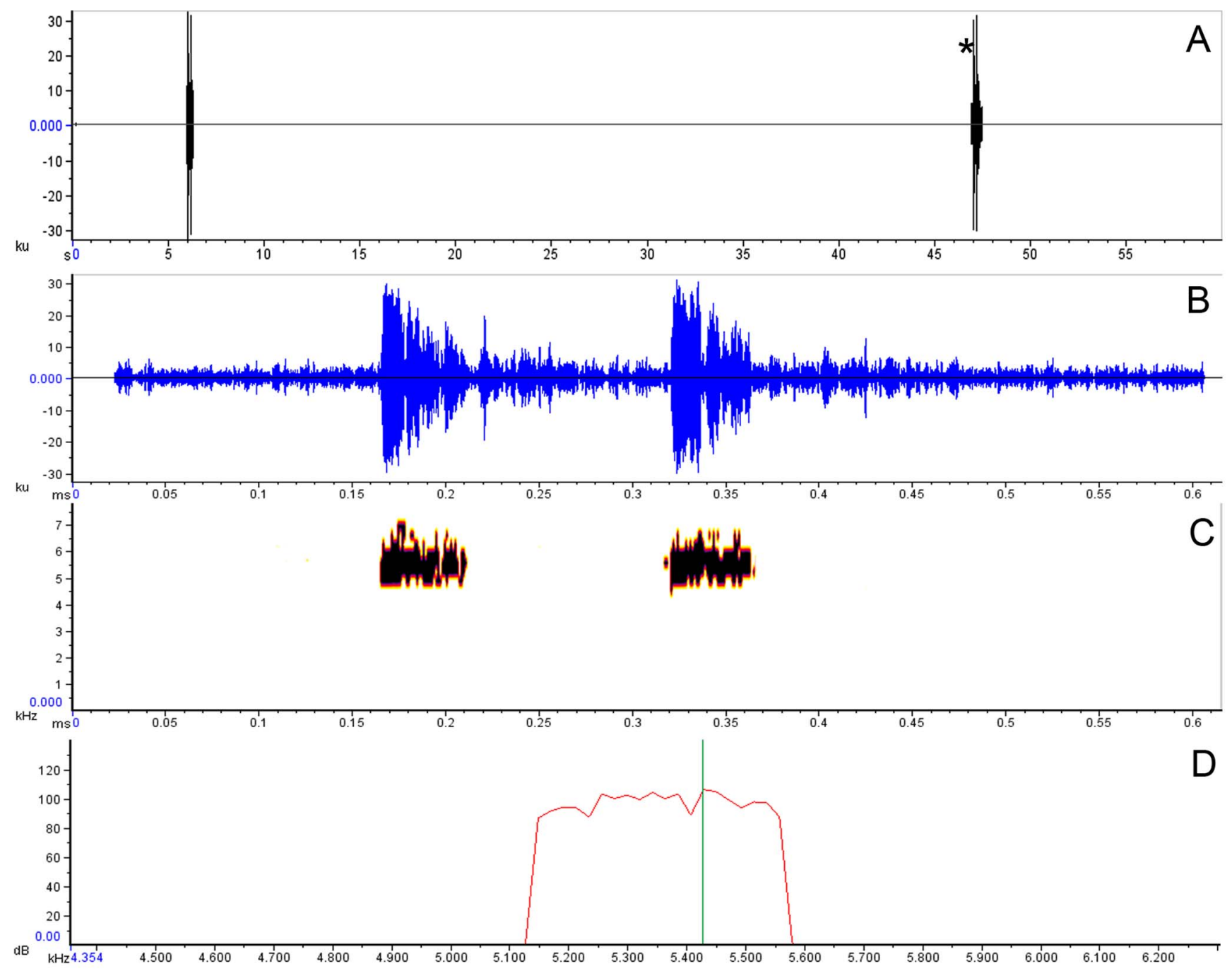

Figure 4. Predation in Cochranella mache. (A) The snake Leptodeira septentrionalis and (B) a Ctenid spider at Bilsa Biological Station, northwestern Ecuador. Photographs by C. Paucar. doi:10.1371/journal.pone.0081837.g004

feebly. The spider had bitten the frog on the left gular region and shoulder, which showed a hemorrhage-like discoloration. After approximately 5 minutes, the frog ceased struggling, and the spider, still holding the frog by the shoulder, repositioned it. The frog tried to escape, striking his hind limbs toward the spider and

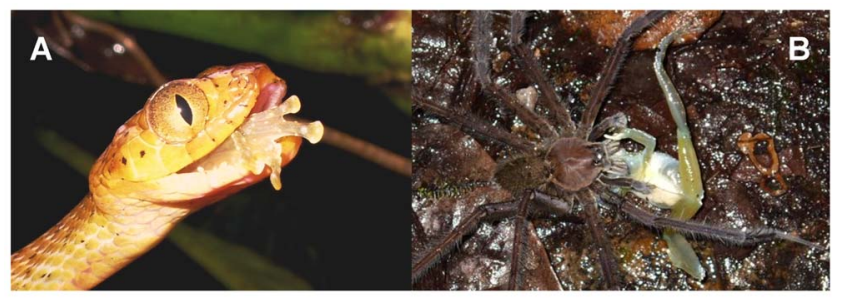

Figure 5. Call of Cochranella mache. (A) Section oscillogram, (B) call oscillogram, (C) spectrogram and (D) power spectrum generated from a calling male recorded at 2254 h, 9 May 2008, Rompe-frente rivulet at Bilsa Biological Station. The second call $\left(^{*}\right)$ was used to analyze acoustic data in (B-D). Green line in (D) marks the peak frequency $(5426.4 \mathrm{~Hz})$ in the band spectrum.

doi:10.1371/journal.pone.0081837.g005 turning over onto its back, with its arms. After 8-10 minutes, the frog was immobilized and eaten by the spider.

\section{Potential distribution model}

The effective presence extension range result in a convex hull polygon within ca. $\sim 6,940 \mathrm{~km}^{2}$, located in northwestern Ecuador. MaxEnt approach algorithm predicted an environmental suitability area for C. mache from 48,509 $\mathrm{Km}^{2}$ to $65,147 \mathrm{Km}^{2}$ (depending on the MTP or T20 thresholds, respectively), with an elongated and curved shape, located from western Ecuador to the southern limit of adjacent Colombia (Fig. 6A). The most important environmental variables to model the suitability areas for C. mache are shown in Table 2. The projected potential distribution model of C. mache (Fig. 6B-C) was trained using seven localities, showing high and significant success rates in jackknife tests with a threshold of $20 \%$ (T20 $=0.12, P=0.01)$, rather than the minimum training presence $(\mathrm{MTP}=0.31, P=0.16)$. The minimum training presence approach $(\mathrm{MTP})$ can be interpreted ecologically as identifying pixels predicted as being at least as suitable as those pixels where the species has been recorded, whereas the Fixed cumulative value (T20) rejected only the lowest $20 \%$ of possible predicted values in 

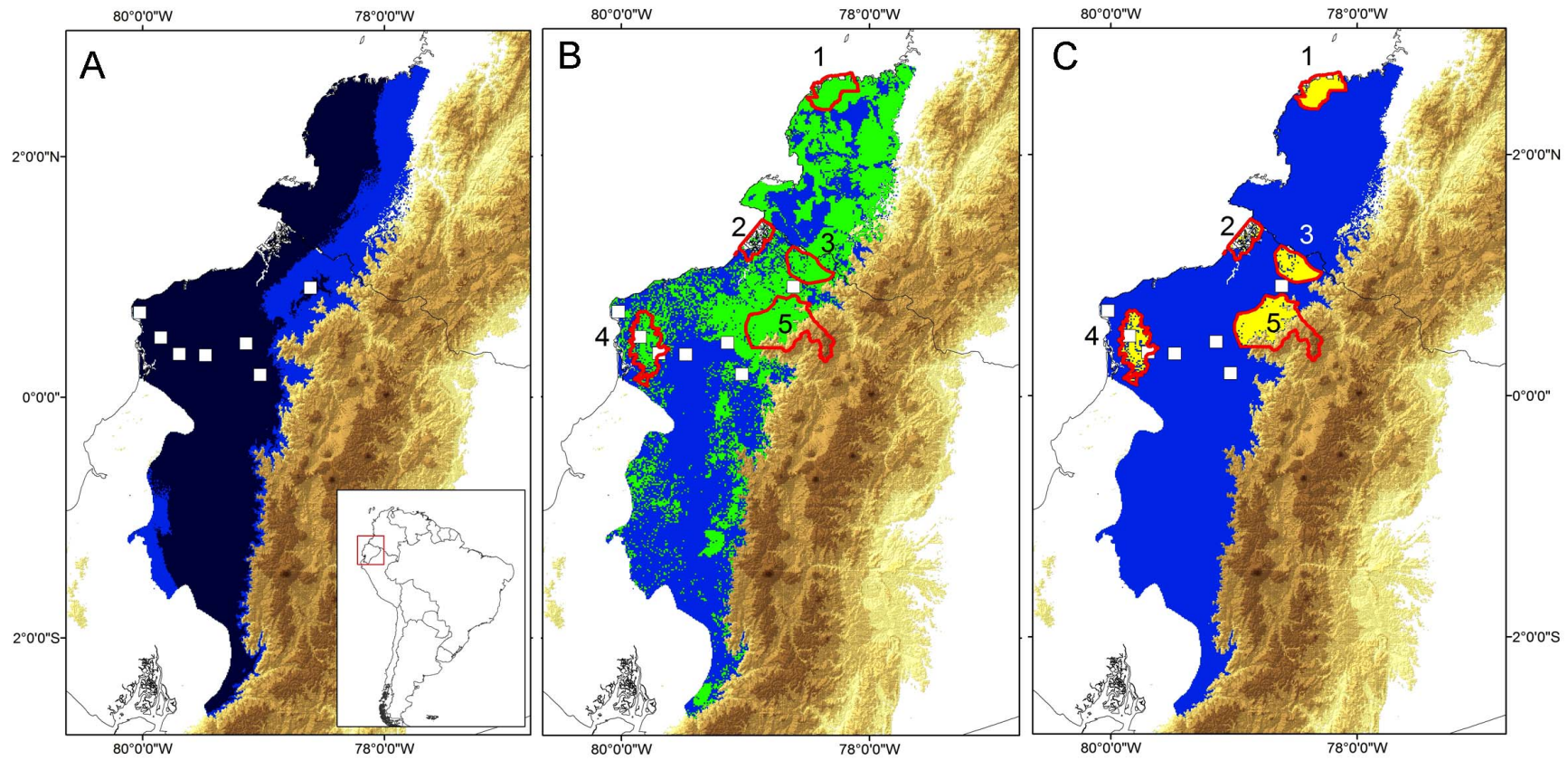

Figure 6. Potential distribution model of Cochranella mache. (A) Potential distribution model is shown with two thresholds, the minimum training presence approach (MTP, dark blue) and Fixed cumulative value of $20 \%$ (T20, light blue); (B) Remnant potential distribution model with natural forests (green areas); (C) Remnant potential distribution model predicted in the National System of Protected Areas of Ecuador and Colombia (yellow areas bordered by red). Squares symbols represents localities used to generate the models. Numbers in (B-C) correspond to Sanquianga Natural National Park (1), Manglares-Mataje Ecological Reserve (2), Awa Forest Reserve (3), Mache-Chindul Ecological Reserve (4), and CotacachiCayapas Ecological Reserve (5). Note a critical reduction ( $69 \%$, in green) of the best-predicted potential distribution model (T20 threshold), when it was filtered by areas with natural forests (B), and over $95 \%$ when it was filtered by Protected Areas in Ecuador and Colombia (C). The model was generated with the most important environmental variables in MaxEnt (See Materials and methods for details, but Table 2). doi:10.1371/journal.pone.0081837.g006

the model. The first approach in this case was more conservative and strict than the second, in which a larger predicted area is incorporated through the model. Then, the MTP model is a subconjunct in the geographic space of T20 model. The potential distribution model is related with Tropical evergreen lowland forest of Ecuador and Colombia $(\sim 66 \%)$, Tropical piedmont forests in the western slopes of Andes $(\sim 28 \%)$, Tropical evergreen low montane forest of western Andes $(\sim 5 \%)$ and Tropical montane forest in the Coastal Range of Ecuador (1\%).

Predicted and remnant areas of the potential distribution model of $C$. mache in protected areas along western Ecuador and adjacent Colombia are detailed in Tables 3 and 4. The model resulted in isolated fragments of natural forest included in protected areas $\left(\sim 5243 \mathrm{~km}^{2}\right.$; Fig. 6$)$ with a reduction which represents $\sim 92 \%$ of the potential distribution model (Table 3 ).

\section{Impacts of deforestation on the distribution model.}

Intensive deforestation reduced by $\sim 70 \%$ the predicted potential geographic range of Cochranella mache (Table 3). Deforestation impacting current predicted range is most intensive across the western Andean foothills (along the roads that connect the capitals and main towns of the coastal Provinces in Ecuador and southern Colombia); on the lowland forest in Coastal region (Esmeraldas-Manabí area) and southern mountain slopes (Los Ríos, Santo Domingo, Manabí, Cotopaxi, provinces) of Central Andes (Fig. 6B). A critical reduction of $95 \%$ of the distribution

Table 2. Summary of the most important environmental variables selected by MaxEnt, with relative contributions in the ecological niche model of Cochranella mache.

\begin{tabular}{lll}
\hline Abbreviation & Environmental Variable & Percent contribution \\
\hline Bio 2 & Mean diurnal temperature range (mean of monthly [maximum temperature - minimum temperature]) & 62.0 \\
Bio 18 & Precipitation of warmest quarter & 19.9 \\
Bio 19 & Precipitation of coldest quarter & 11.7 \\
Bio 14 & Precipitation of the driest month \\
Bio 6 & Maximum temperature of warmest month \\
Bio 3 & Isothermality (BIO2/BIO7 x 100) \\
Bio 7 & Temperature range (maximum temperature of the warmest month - minimum temperature of the coldest 0.1 \\
\hline
\end{tabular}

doi:10.1371/journal.pone.0081837.t002 
model of C. mache is identified when combine data of deforestation and remnant model included into the limits of Protected Areas (Table 3); in contrast, about $85 \%$ of forested areas within the model is located out from the limits of Protected Areas (Fig. 6C).

\section{Future scenarios under climate change}

Potential geographic ranges projected under two different climate change scenarios (CCCMA-A2 and CCCMA-B2 climatic models, which not consider current deforestation) for Cochranella mache from western Ecuador are presented on Figure 7. Reductions of the predicted geographic range caused by current deforestation and preserved in Protected Areas generated by both climate change scenarios are detailed in Table 3. Suitability areas for Cochranella mache are predicted to be reduced in extension, especially along the northern part of the model, mainly in lowlands of southwestern Colombia (Fig. 7). Likely to occur with the potential distribution model, the largest impact will be due by deforestation, since climate change alone will represent a net reduction of $13-21 \%$ of its future predicted geographic range (Table 3).

The amount of reduction of the predicted geographic ranges related with Protected Areas is critical in Sanquianga Natural National Park (Colombia), either in "Pessimistic" or "Optimistic" climate change scenarios (Fig. 8). However, among Ecuadorian' Protected Areas, a total reduction of habitat suitability is only observed in Manglares-Mataje Ecological Reserve when is evaluated within a "Pessimistic" scenario, whereas in the other three reserves the reduction of predicted potential geographic range results minimum (Fig. 8).

\section{Discussion}

In the present study we monitored a population in northwestern Ecuador to assess abundance patterns and natural history aspects of the endangered frog, C. mache. We were able to find additional specimens in museum collections from two new localities and present a proposal of potential distribution model based on relevant environmental data, even in two future scenarios of climate change. This approach was useful to evaluate the effectiveness of protected areas in western Ecuador and adjacent southern Colombia, and it has the potential to be used as guide to evaluate other uncommon endangered species in the Neotropics.

\section{Natural history}

Monitoring a C. mache population in Bilsa Biological Station (BBS) revealed that the species breeds at night after loud rains, during rainy season (January to June). When breeding season begins, males frequently call from midstory and canopy vertical forest stratums, or perching on leaves from surrounding vegetation up to 4 meters above ground. This species is restricted to small streams and rocky rivulets at primary and old secondary forests, with close canopy cover [16]. Cisneros-Heredia et al. [39] reported the first known gravid female in Canandé Biological Reserve, Esmeraldas Province, Ecuador.

Herein we described for first time the mating call for C. mache, being structurally similar to some distantly related species of glassfrogs (e.g. Hyalinobatrachium fleischmanni), mainly by the pulsed shape of waveform in the oscillogram and the range of dominant frequencies (http://zoologia.puce.edu.ec/Vertebrados/anfibios/ Cantos.aspx? Id = 3188). Among specific localities (small rivulets) where C. mache has been found, H. fleischmanni was not present. This could be because the latter species seems to prefer broader and torrential rivers in western Ecuador, rather than small rivers and creeks [55]. Furthermore, the reports of an amplectant pair and a gravid female (April 2009), and the abundance pattern found in Bilsa support the hypothesis that this species is a breeder throughout the rainy season, similar to other syntopic species which seems to have a different matting call structure and behavior (e.g. Sachatamia albomaculata, Hyalinobatrachium valerioi, [5557]). No clutched eggs were seen through surveys but, it is possible that females of $C$. mache deposit their eggs on the upper sides of leaves along streams as other related species do [58].

Predation is often invoked as a population-regulating mechanism and as a factor that contributes to shape community structure [59-61]. The observations in the field are noteworthy because little is known about predation on centrolenids [62]. Here we describe for the first time the predation behavior on $C$. mache by a snake, Letodeira septentrionalis, and a Cnetid spider, Cnetus sp. As observed in other tropical frogs [63], snakes from genus Leptodeira seem to be an important predator in communities throughout the breeding season in lowland tropical forest of northwestern Ecuador [64]. Predation by spiders seems to affect early and late life history stages in C. mache, whereas predation on arboreal egg masses has been reported by grapsid crab (Sesarma roberti Edwards), phalangids (Prionostemma frontale Banks), and gryllids (Paroecanthus

Table 3. Potential distribution area of Cochranella mache and percentage of such distribution under two scenarios of climate change (CCCMa-A2, CCCMa-B2), effect of habitat loss and remnant model included in protected areas in northwestern Ecuador and southern Colombia.

\begin{tabular}{|c|c|c|c|c|}
\hline Model & T20 $\left(\sim \mathrm{km}^{2}\right)$ & $\%$ & $\operatorname{MTP}\left(\sim \mathbf{k m}^{2}\right)$ & $\%$ \\
\hline Potential distribution area & 65147 & 100 & 48509 & 100 \\
\hline Area of the model with natural forests & 19942 & 31 & 11987 & 25 \\
\hline Area of the model included in Protected Areas & 5243 & 8 & 3133 & 6 \\
\hline Remnant model within Protected Areas and natural forests & 3096 & 5 & 1701 & 4 \\
\hline Model under CCCMA-A2 & 51533 & 79 & 37965 & 78 \\
\hline Area of the model with natural forests & 14095 & 22 & 7793 & 16 \\
\hline Area of the model included in Protected Areas & 3967 & 6 & 2411 & 5 \\
\hline Model under CCCMA-B2 & 56576 & 87 & 44082 & 91 \\
\hline Area of the model with natural forests & 16281 & 25 & 10540 & 22 \\
\hline Area of the model included in Protected Areas & 4224 & 6 & 3388 & 7 \\
\hline
\end{tabular}

Logistic threshold decision was applied on models with a Minimum training presence (MTP) and Fixed cumulative value of $20 \%$ (T20, but see Materials and Methods). doi:10.1371/journal.pone.0081837.t003 
Table 4. Potential distribution model of glassfrog Cochranella mache, in $\mathrm{Km}^{2}$ (percentages), predicted for protected areas in western Ecuador (Ecu) and southern Colombia (Col).

\begin{tabular}{|c|c|c|}
\hline Protected area & T20 & MTP \\
\hline 1. Sanquianga Natural National Park (Col) & $904(17 \%)$ & $904(29 \%)$ \\
\hline 2. Manglares-Mataje Ecological Reserve (Ecu) & $205(4 \%)$ & $205(7 \%)$ \\
\hline 3. Awa Forest Reserve (Ecu) & $937(18 \%)$ & $106(3 \%)$ \\
\hline 4. Mache-Chindul Ecological Reserve (Ecu) & $1433(27 \%)$ & 1433 (46\%) \\
\hline 5. Cotacachi-Cayapas Ecological Reserve (Ecu) & $1764(34 \%)$ & $465(15 \%)$ \\
\hline Total predicted model in Protected Areas & $5243(100 \%)$ & $3113(100 \%)$ \\
\hline \multicolumn{3}{|c|}{$\begin{array}{l}\text { Logistic threshold decision was applied on a models with a Minimum training } \\
\text { presence (MTP) and Fixed cumulative value of } 20 \% \text { (T20; see Materials and } \\
\text { methods for details). Ordered numbers correspond to the identity label in } \\
\text { Figures } 6-7 \text {. } \\
\text { doi:10.1371/journal.pone. } 0081837.004\end{array}$} \\
\hline
\end{tabular}

tibialis Saussure and Pictet) in other tropical glassfrogs [62]. The modus operandi by Ctenid spider in C. mache was likely similar to that described for the spider Cupiennus sp. (Cnetidae) on Espadarana prosoblepon and Hyalionobatrachium fleischmanni, being one of the most important predators, on adult stages, of some glassfrogs in Costa Rica [62]. More data are needed, but spiders and snakes may prove to be one of the most important predators on small terrestrial anurans and their developmental stages in riverine habitats.
High richness of glassfrogs occurs along the lowlands of extreme northwestern Ecuador, with fewer species in areas closer to the Cordillera Occidental. At least, five additional glassfrogs have been reported as sympatric with $C$. mache in rivulets in Bilsa Biological Station [34]: Espadarana prosoblepon (Boettger), Sachatamia albomaculata (Taylor), Teratohyla pulverata (Peters), Hyalinobatrachium fleischmanni Boettger, and H. valerioi Dunn.

\section{Species distribution model for Cochranella mache}

Working on unexplored areas produces frequently new species descriptions [65-69], expansions of known species' distribution ranges [70-73] and records of unidentified specimens on biological inventories $[69,74]$. Thus, the application of technology for modeling ecological niches and predicting geographic distributions is extremely useful in defining core areas of species diversity, foci of undiscovered species and developing conservation strategies [24,75-77]. In this context, modeling with small number of occurrence records needs a valuation in the fitting of the obtained model, to do a correct interpretation, identify regions with similar environmental conditions and to predict limits in the species' distribution range [24,78]. Herein, an exploratory model based on small sample size predicts a suitability area located from lowland forest in southwestern Colombia, through northwestern Ecuador and continued to Foothill montane forest in western Andes. An apparent over-predicted area is located in the south of the environmental suitability model, along the and manglar in Jama-Zapotillo Biogeographic Province. Since records of C. mache are mainly related to tropical forests in Western Ecuadorian
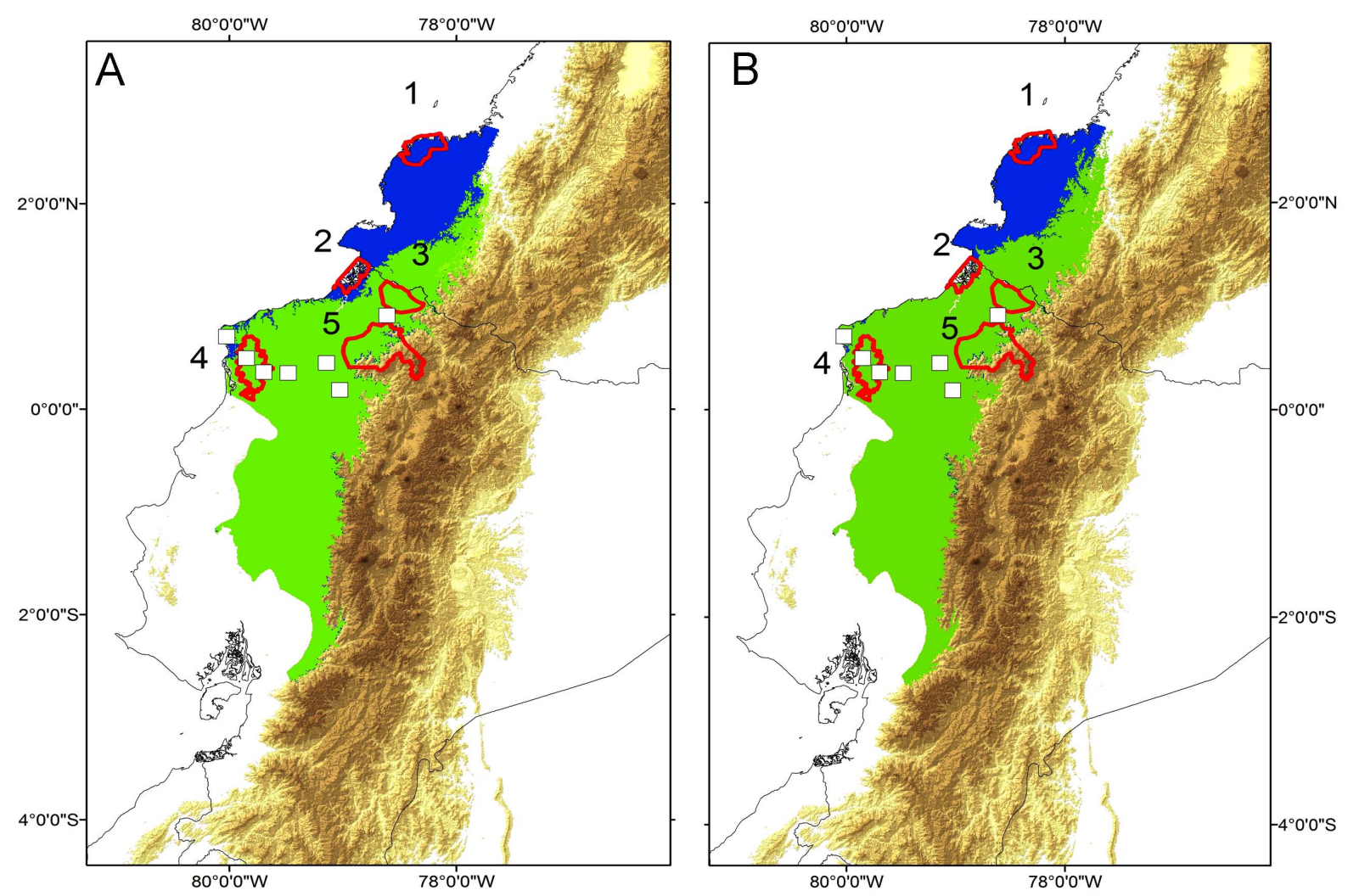

Figure 7. Potential distribution model of Cochranella mache in two future scenarios of climate change. Potential distribution model in year 2050, under the GCM's Canadian model (A) CCCMA-A2 ("pessimistic") and (B) CCCMA-B2 ("optimistic") climatic scenarios. Note a reduction $(\sim 20 \%$, in green) of the best-predicted potential distribution model (T20 threshold), especially located in the northwestern part of the model. In both scenarios, suitability areas for Cochranella mache tend to loss in Sanquianga Natural National Park (1) and Manglares-Mataje Ecological Reserve (2). doi:10.1371/journal.pone.0081837.g007 


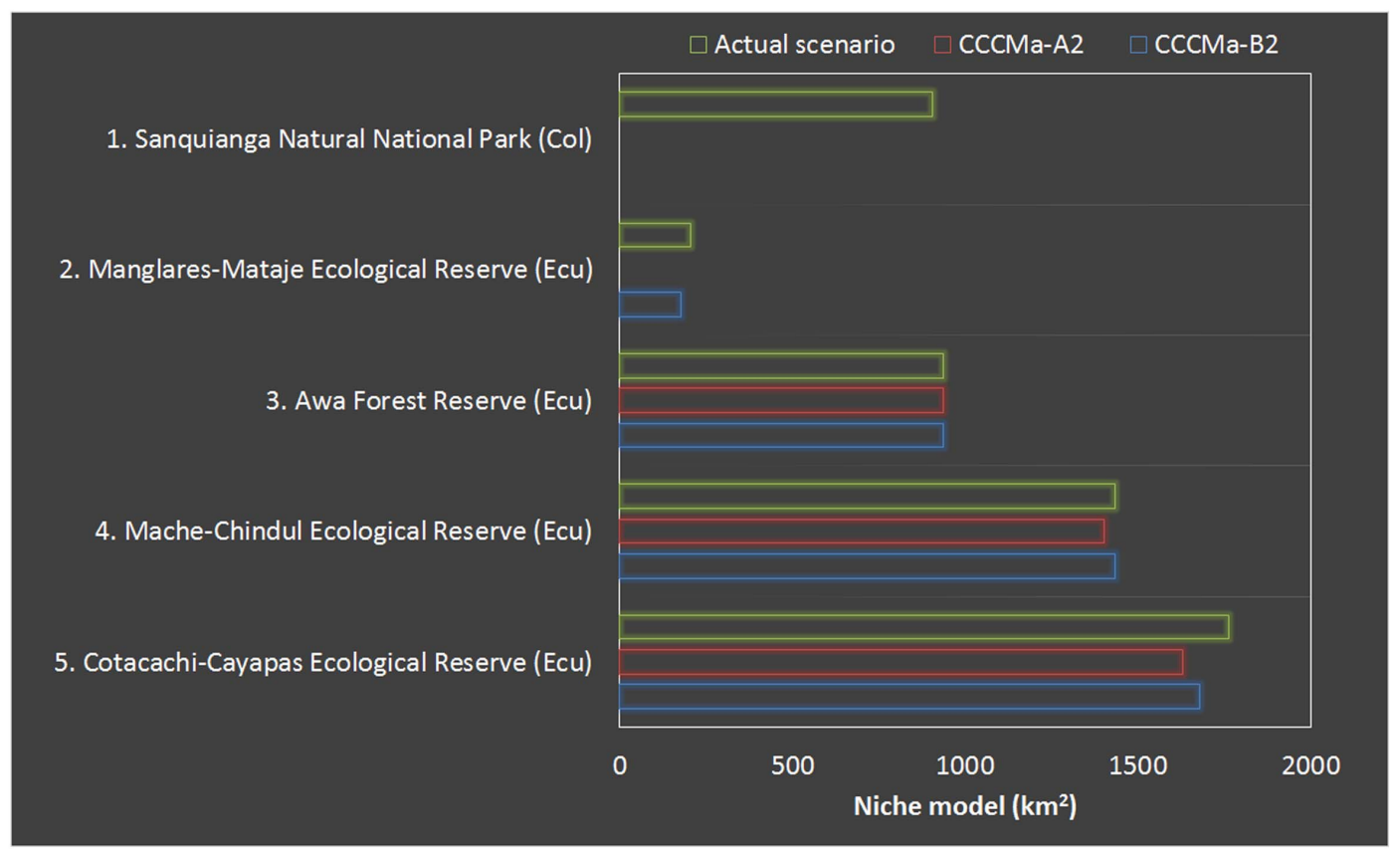

Figure 8. The role of protected areas in two future scenarios of climate change. In scenarios of climate change, the amount of reduction of the predicted geographic range is critical for Cochranella mache in Sanquianga Natural National Park (1) and Manglares-Mataje Ecological Reserve (2), whereas in the other three reserves, the reduction of the predicted potential geographic range results minimum. doi:10.1371/journal.pone.0081837.g008

Biogeographic Province, these predicted areas could reflects potential habitats not colonized due by biogeographic barriers [23] or areas that may conserve the niche from extinct populations $[24,27]$. To prove these hypotheses, field explorations must be planning in order to assess potential new records for C. mache in central-western Ecuador.

As result of niche modeling, the less conservative model (T20) predicts a best potential species distribution area, which is restricted for the species $\left(\sim 65,147 \mathrm{Km}^{2}\right)$ along the seasonal evergreen forests of the West Ecuadorian region, in the Cordillera Mache-Chindul, eastern Piedmont Andean forest and adjacent coastal Colombia. In the absence of local herpetological surveys, the latter area is proposed for future field surveys, as well as the Piedmont forest located in western Andes, along the limit frontier between Ecuador and Colombia.

Predicted suitability areas from small numbers of occurrence records have great results, especially in targeting field surveys to accelerate the discovery of unknown populations and species $[24,42,79]$. For example, the study of models generated for relative close phylogenetic species (e.g. C. resplendens, C. litoralis), which also are threatened and scarce in collections, could give us a better idea about the biogeography and the processes involved in the speciation patterns of glassfrogs in northern Andes. Moreover, the addition of new records from future field surveys has the potential to impact model predictions and clarify our understanding on the distribution of uncommon species $[79,80]$. The model match with a relatively small biogeographic region, the Western Ecuador Province [32], different from the Choco and Tumbesian regions. However, further research is required to investigate population declines and targeting surveys, in order to accelerate the discovery of unknown populations on unexplored areas with high probability of relative suitability $[24,79]$.

As noted before, C. mache is a canopy dweller restricted to small streams and rivulets at primary and old secondary forest, considered as a sensitive species to habitat disturbances. In this context, a critical reduction of the potential distribution model $(\sim 92 \%)$ is predicted after we applied a filter for Protected Areas in Ecuador and Colombia, being the Mache-Chindul and CotacachiCayapas Ecological Reserves the most important for C. mache in the best-fitted model. Strong anthropogenic pressures have been reported for both Reserves, mainly related with an expansion of the agricultural frontier, grass for cattle, wood extraction, illegal mining and possession of land [81,82]. Furthermore, a critical aspect found in management plans for these reserves reveals a none programmatic strategy to deal with threatened amphibians, in spite that the inventories reported that at least one third of the frogs are considered as threatened or endemic [34,81,82].

The suitability model predicted for $C$. mache is severely reduced when we applied the effect of habitat loss, even inside of Protected Areas ( $~ 95 \%$ of reduction, Table 3$)$. When the model is evaluated in two futures scenarios of climate change, it is clear a reduction in the northern part, encompassed with coastal lowland forest in Colombia and the limits along the northern frontier with Ecuador. In scenarios of climate change, the amount of reduction of the predicted geographic ranges related with Protected Areas in Sanquianga Natural National Park (Colombia) and ManglaresMataje Ecological Reserve is critical, whereas in the other three reserves the reduction of predicted potential geographic range result minimum (Fig. 8). The fact that three reserves (Awa Forest Reserve, Mache-Chindul Ecological Reserve, Cotacachi-Cayapas Ecological Reserve) presented a minimum reduction of suitability areas on future scenarios of climate change (Fig. 8), may recommend focal sites to invest efforts in develop conservation strategies in these National Protected Areas in western Ecuador. Nevertheless, it is necessary to highlight that a synergy based on habitat loss and climate change may have significant impacts on habitat suitability for this species, even more than both factors evaluated by separated along the distributional range and Protected Areas (Table 3). In this context, our results supports other studies in which these threats, even with synergetic effects by 
pathogens and climate change, are potential causes for critical declines in amphibian species with restricted distributional ranges $[13,16]$.

Deforestation and extension of agricultural frontier are both the most important factors in habitat and biodiversity loss in Neotropics [83-86]. For example, as 70\% of natural forests across western Ecuador have been felled [87-90], probably inducing changes in local climate patterns of nearby well-preserved areas and thus affected amphibians [13,17], but with a higher impact degree due to the restricted geographic ranges of some centrolenid species [91], as probably occurs with C. mache.

\section{Conservation status of Cochranella mache}

This frog was globally classified as "Endangered" by Guayasamin [92] under criteria Blab(iii) because "the extent of occurrence is likely to be less than $5000 \mathrm{~km}^{2}$, essentially known from one location, and suspects that its habitat is undergoing continuing declines in extent, although the known range of this species is encompassed by protected areas". Prior to this research, we only had reports from seven specimens of $C$. mache related to five localities assessed through $\sim 286$ person/hours in samplings along northwestern Ecuador. These data was used to promote the re-categorization to Critically Endangered of the species [16]. However, Ron et al. [17] suggested this species should be nationally listed as Data Deficient.

New data provided in this research reveals that C. mache could have a wider and more abundant distribution than it was previously thought. Now we have confirmed reports of at least seven localities in northwestern of Ecuador. According to the species distribution model and historical data of distribution, this species is restricted to three vegetation formations: Foothill evergreen forests of coastal Mountains, Lowland evergreen forest and Piedmont evergreen forests of western Ecuador, being probable its presence in adjacent Colombia, in an altitudinal range up to $1000 \mathrm{~m}$ asl. In Ecuador, these vegetation types had a historical extension of ca. $\sim 46,508 \mathrm{~km}^{2}$; today ca. $\sim 75 \%$ has been severely affected by anthropogenic activities with less than $25 \%$ remaining [90,93-95]. Furthermore, about $85 \%$ of the remnant distribution model for C. mache correspond to natural forest located out from Protected Areas.

We have at least two possible scenarios to evaluate the conservation status based on the distribution of the species: (1) conservation status assuming that the presence extension range is accurate, and (2) conservation status assuming that the distribution model is accurate. For the former scenario, the presence extension range for this species is near than $6,940 \mathrm{~km}^{2}$, where are extensively fragmented and continued declines of its extent and habitat quality. Since the species was described very recently [40], it is probable that the distribution of C. mache is likely larger than a polygon of the presence extension range, but a less number of potential undiscovered localities and subpopulations in an effective

\section{References}

1. Donnelly M, Crump M (1998) Potential effects of climate change on two Neotropical amphibian assemblages. Climatic Change 39: 541-561.

2. IUCN (2012) The IUCN Red List of Threatened Species. Cambridge GB3 0DL, UK: International Union for Conservation of Nature and Natural Resources.

3. Sánchez D, Chacón-Ortiz A, León F, Han BA, Lampo M (2008) Widespread occurrence of an emerging pathogen in amphibian communities of the Venezuelan Andes. Biological Conservation 141: 2898-2905.

4. Whiles M, Lips K, Pringle C, Kilham S, Kilham S, et al. (2006) The Effects of Amphibian Population Declines on the Structure and Function of Neotropical Stream Ecosystems. Frontiers in Ecology and the Environment 1: 27-34.

5. Young BE, Stuart SN, Chanson JS, Cox NA, Boucher TM (2004) Disappearing Jewels: The Status of NewWorld Amphibians. Arlington, Virginia: NatureServe. $53 \mathrm{p}$. occupancy area is probable among surrounding localities, mainly by habitat loss. In a second scenario, the potential distribution model reach $\sim 65.147 \mathrm{~km}^{2}$, but a reduction in about $70 \%$ of the area is inferred only by habitat loss, being not more than $5 \%$ of the potential distribution model conserved into the SNAP (Table 3). As noted before, in both scenarios a critical reduction in the area of occurrence and ecological suitability is estimated for this species (Figs. 6-8).

According with reports of a half of centrolenid species which are declining and threatened with extinction [16,17,96,97], we suspect that a reduction $\geq 50 \%$ of the population size is possible in the next decades. Moreover, based on the predicted model of distribution, the current extension or remaining ecological suitable habitats in Protected Areas range is less than $5000 \mathrm{~km}^{2}$, being progressively reduced by extreme fluctuation in forest coverture in nearby areas of Ecological reserves. Besides, the potential effect of climate change might represent a synergetic risk, especially in the northern part of the model, where few Protected Areas are located (Figs.7-8).

Considering these arguments, we recommend that C. mache must be re-categorized as "Critically Endangered" species in national and global status, according with criteria and sub-criteria A4, B lab(i,ii,iii,iv),E [51], based in a probable extinction $\geq 50 \%$ of local populations in the next generations by synergetic effects of habitat loss and climate change.

\section{Acknowledgments}

We thank M. E. Barragán, J. Valencia, and K. Garzón from Fundación Herpetológica Gustavo Orcés; S. Ron from the Museo de Zoología, Departamento de Ciencias Biológicas, Pontificia Universidad Católica del Ecuador; L. Coloma from Centro Jambatu, and M. Yánez-Muñoz from Museo Ecuatoriano de Ciencias Naturales, for laboratory assistance and for allowing the revision of the herpetological collections under their management. We are indebted to J. Valencia, D. F. Cisneros-Heredia, J.M. Guayasamin, F. Ayala, L. Coloma, G. Vigle, G. Jongsma, and J. Bermingham whose generously shared information and comments on specimens collected in Ecuador; to R. Landgrave (Instituto de Ecología, A.C.) and E. Martínez-Meyer (Instituto de Biología, Universidad Nacional Autónoma de México) for advice regarding to model design and background analysis. We especially thank M. Asanza, C. Aulestia and J. Bermingham (Fundación Jatun Sacha) for supporting field work at Bilsa Biological Station. Angelina Ruiz helped in the improving of the manuscript. The research authorization $\left(\mathrm{N}^{\circ} 2\right)$ was issued by the Ministerio del Ambiente de Ecuador. This article has benefited from valuable criticisms made by Christopher Joseph Salice and two anonymous reviewers.

\section{Author Contributions}

Conceived and designed the experiments: HMO-A. Performed the experiments: HMO-A CP. Analyzed the data: HMO-A OR-S. Contributed reagents/materials/analysis tools: HMO-A. Wrote the paper: HMOA OR-S

6. Palacios E, Cáceres L (1998) Análisis de vulnerabilidad y adaptación. Escenarios del cambio climático en Ecuador. Quito-Ecuador.

7. Pearman P (1997) Correlates of amphibian diversity in an altered landscape in Amazonian Ecuador. Conserv Biol 11: 1211 - 1225.

8. Bosch J, L. M Carrascal, L Durán, S Walker, M. C Fisher (2006) Climate change and outbreaks of amphibian chytridiomycosis in a montane area of Central Spain; is there a link? Proceedings of the Royal Society B 10: 1-8.

9. Bustamante MR, Ron SR, Coloma LA (2005) Cambios en la Diversidad en Siete Comunidades de Anuros en los Andes de Ecuador. Biotropica 37: 180189.

10. Corn PS (2005) Climate change and amphibians. Animal Biodiversity and Conservation 28: 59-67. 
11. La Marca E, Lips K, Lötters S, Puschendorf R, Ibáñez R, et al. (2006) Catastrophic Population Declines and Extinctions in Neotropical Harlequin Frogs (Bufonidae: Atelopus). Biotropica 37: 190-201.

12. Mejía R, Ontaneda G, Cáceres L (1998) Evidencias del cambio climático en el Ecuador. Quito-Ecuador.

13. Menéndez-Guerrero PA, Graham CH (2013) Evaluating multiple causes of amphibian declines of Ecuador using geographical quantitative analyses. Ecography 36: 1-14.

14. IUCN (2003) Directrices para emplear los criterios de la Lista Roja de la UICN a nivel regional: Versión 3.0. Reino Unido: Comisión de Supervivencia de Especies de la UICN. UICN, Gland, Suiza y Cambridge. 26 p.

15. IUCN (2006) Habitats Authority File. 2.1. ed: International Union for Conservation of Nature and Natural Resources.

16. Cisneros-Heredia D, Delia J, Mario H, Ortega-Andrade H (2009) Endemic Ecuadorian glassfrog Cochranella mache is Critically Endangered because of habitat loss. Oryx 44: 114-117.

17. Ron SR, Guayasamin JM, Menéndez-Guerrero P (2011) Biodiversity and conservation status of Ecuadorian Amphibians. In: Heatwole H, L. B-AC, Wilkinson HW, editors. Amphibian Biology Part 2. Baulkham Hills, Australia: Surrey Beatty \& Soons PTY Limited. pp. 129-170.

18. Stockwell D, Peterson A (2002) Effects of sample size on accuracy of species distribution models. Ecological Modelling 148: 1-13.

19. Buckland S, Elston D, Beaney S (1996) Predicting distributional change, with application to bird distributions in northeast Scotland. Global Ecology and Biogeography Letters: 66-84

20. Hirzel A, Hausser J, Chessel D, Perrin N (2002) Ecological-niche factor analysis: how to compute habitat-suitability maps without absence data? Ecology 83: 2027-2036.

21. Stockwell D (1999) The GARP modelling system: problems and solutions to automated spatial prediction. International Journal of Geographical Information Science 13: 143-158.

22. Urbina-Cardona JN, Loyola RD (2008) Applying niche-based models to predict endangered-hylid potential distributions: are neotropical protected areas effective enough? Tropical Conservation Science 1: 417.

23. Soberón J, Peterson A (2005) Interpretation of models of fundamental ecological niches and species' distributional areas. Biodiversity Informatics 2.

24. Pearson R, Raxworthy G, Nakamura M, Peterson A (2007) Predicting species distributions from small numbers of occurrence records: a test case using cryptic geckos in Madagascar. Journal of Biogeography 34: 102-117.

25. McPherson J, Jetz W, Rogers D (2004) The effects of species' range sizes on the accuracy of distribution models: ecological phenomenon or statistical artefact? Journal of Applied Ecology 41: 811-823.

26. Wiens J (2007) Global patterns of diversification and species richness in amphibians. The American Naturalist 170: 86-106.

27. Wiens J, Graham C (2005) Niche conservatism: Integrating evolution, ecology, and conservation biology. Annual Review of Ecology, Evolution and Systematics 36: 519-539.

28. Cuesta-Camacho F, Peralvo M, Ganzenmüller A, Sáenz M, Novoa J, et al. (2007) Identificación de vacios y prioridades para la conservación de la biodiversidad terrestre en el Ecuador continental. In: Beltrán K, Campos F, Clark K, Cuesta-Camacho F, Denkinger J et al., editors. Análisis de vacios y áreas prioritarias para la conservación de la biodiversidad en el Ecuador continental. Quito, Ecuador: Instituto Nazca de Investigaciones Marinas, EcoCiencia, Ministerio del Ambiente, The Nature Conservancy, Conservación Internacional. pp. 83

29. Hutchinson GE (1957) Concluding Remarks. Cold Spring Harbor Symposia on Quantitative Biology 22: 415-442.

30. Phillips S, Anderson R, Schapire R (2006) Maximum entropy modeling of species geographic distributions. Ecological Modelling 190: 231-259.

31. Pianka ER (1988) Evolutionary ecology. New York. United States of America: Fourth Edition. The University of Texas at Austin.

32. Morrone JJ (2002) Presentación sintética de un nuevo esquema biogeográfico de América Latina y el Caribe. In: Costa C, Vanin SA, J.M L, Melic A, editors. Proyecto de Red Iberoamericana de Biogeografia y Entomología Sistemática. Zaragoza, Julio-2002: m3m : Monografias Tercer Milenio vol. 2. pp. 267-276.

33. Cerón C, W P, Valencia R, Sierra R (1999) Las Formaciones Naturales de la costa del Ecuador. In: Sierra R, editor. Propuesta preliminar de un Sistema de Clasificación de Vegetación para el Ecuador Continental. Quito, Ecuador. pp. $55-73$.

34. Ortega-Andrade HM, Bermingham J, Aulestia C, Paucar C (2010) Herpetofauna of the Bilsa Biological Station, province of Esmeraldas, Ecuador. Check List 6: 119-154

35. Hammer O, Harper DA, Ryan PD (2001) PAST: Paleontological Statistics software package for education and data analysis. Paleontological Electronica 4:

36. Angulo A (2006) Fundamentos de bioacústica y aspectos prácticos de grabaciones y análisis de cantos. In: Angulo A, Rueda-Almondacid JV, Rodríguez-Mahecha JV, La Marca E, editors. Técnicas de inventario y monitoreo para los anfibios de la Región Tropical Andina. Bogotá, Colombia: Conservación Internacional, Serie Manuales de Campo. pp. 93-134.

37. Cocroft RB, Ryan MJ (1995) Patterns of advertisement call evolution in toads and chorus frogs. Animal Behaviour 49: 283-303.
38. Hutter CR, Guayasamin JM (2012) A new cryptic species of glassfrog Centrolenidae: Nymphargus) from Reserva Las Gralarias, Ecuador. Zootaxa 3257: 1-21.

39. Cisneros-Heredia DC, Delia J, Yánez-Muñoz M, Ortega-Andrade HM (2008) Natural history and intraspecific variation of the Ecuadorian Blue Glassfrog Cochranella mache Guayasamin \& Bonaccorso, 2004. Herpetozoa 21: 57-66.

40. Guayasamin JM, Bonaccorso E (2004) A new species of glass frog (Centrolenidae: Cochranella) from the lowlands of north western Ecuador, with comments on the Cochranella granulosa group. Herpetologica 60: 485-494.

41. Peterson AT, Vieglais DA (2001) Predicting species invasions using ecological niche modeling: New approaches from bioinformatics attack a pressing problem. BioScience 51: 363-371.

42. Bourg N, McShea W, Gill D (2005) Putting a CART before the search: successful habitat prediction for a rare forest herb. Ecology 86: 2793-2804.

43. Hijmans RJ, Cameron SE, Parra JL, Jones PG, Jarvis A (2005) Very high resolution interpolated climate surfaces for global land areas. International Journal of Climatology 25: 1965-1978.

44. Royle JA, Chandler RB, Yackulic C, Nichols JD (2012) Likelihood analysis of species occurrence probability from presence-only data for modelling species distributions. Methods in Ecology and Evolution 3: 545-554.

45. Rojas-Soto O, Martínez-Meyer E, Navarro-Sigüenza A, Oliveras de Ita A, Gómez de Silva H, et al. (2008) Modeling distributions of disjunct populations of the Sierra Madre sparrow. J Field Ornithol 79: 245-253.

46. Pearson RG, Dawson TP, Liu C (2004) Modelling species distributions in Britain: a hierarchical integration of climate and land-cover data. Ecography 27 : 285-298.

47. Olson DM, Dinerstein E, Wikramanayake ED, Burgess ND, Powell GV, et al. (2001) Terrestrial Ecoregions of the World: A New Map of Life on Earth: A new global map of terrestrial ecoregions provides an innovative tool for conserving biodiversity. BioScience 51: 933-938.

48. MAE (2013) Sistema de Clasificación de los Ecosistemas del Ecuador Continental. QuitoEcuador: Ministerio del Ambiente del Ecuador, Subsecretaría de Patrimonio Natural. 232 p.

49. IDEAM, IGAC, IAvH, IIAP, INVEMAR, et al. (2007) Ecosistemas continentales, costeros y marinos de Colombia. Bogotá D.C.: Instituto de Hidrología, Meteorología y Estudios Ambientales; Instituto Geográfico Agustín Codazzi; Instituto de Investigaciones de Recursos Biológicos Alexander von Humboldt; Instituto de Investigaciones Ambientales del Pacífico John von Neumann; Instituto de Investigaciones Marinas y Costeras-INVEMAR e Instituto Amazónico de Investigaciones Científicas Sinchi. 276 p.

50. IUCN, UNEP-WCMC (2012) Protected Planet - The latest initiative harnessing the World Database on Protected Areas. World Database on Protected Areas (WDPA).

51. IUCN (2001) Categorías y criterios de la Lista Roja de la UICN. 3.1 ed. Cambridge CB3 0DL, UK: International Union for Conservation of Nature and Natural Resources.

52. ESRI (2010) ArcMap 10.0. Environmental System Research Institute, Inc.

53. Bedia J, Herrera S, Gutiérrez JM (2013) Dangers of using global bioclimatic datasets for ecological niche modeling. Limitations for future climate projections. Global and Planetary Change 107: 1-12.

54. IPCC (2007) Climate Change 2007: Synthesis Report. In: Core-Writing-Team, Pachauri RK, Reisinger A, editors. Contribution of Working Groups I, II and III to the Fourth Assessment

55. Report of the Intergovernmental Panel on Climate Change. Geneva, Switzerland. pp. 104

56. Ortega-Andrade HM, Meza-Ramos P, Cisneros-Heredia DF, Yánez-Muñoz M, Altamirano M (2010) Los anfibios y reptiles del Chocó esmeraldeño. In: Altamirano M, Ortega Andrade HM, editors. Serie Herpetofauna del Ecuador: El Chocó esmeraldeño: Quinta Edición. Museo Ecuatoriano de Ciencias Naturales. pp. 95-232.

57. Savage J (2002) The Amphibians and Reptiles of Costa Rica: A Herpetofauna between Two Continents, between Two Seas. Chicago, USA: The University of Chicago Press. 954 p.

58. Vockenhuber EA, Hödl W, Karpfen U (2008) Reproductive behaviour of the glass frog Hyalinobatrachium valerioi (Anura: Centrolenidae) at the tropical stream Quebrada Negra (La Gamba, Costa Rica). Stapfia 88: 335-348.

59. Guayasamin JM, Castroviejo-Fisher S, Trueb L, Ayarzagüena J, Rada M, et al. (2009) Phylogenetic systematics of Glassfrogs (Amphibia: Centrolenidae) and their sister taxon Allophryne ruthveni. Zootaxa 2100: 1-97.

60. Begon M, Townsend CR, Harper JL (2006) Ecology: From Individuals to Ecosystems. Main Street, Malden, MA, USA: Blackwell Publishing. 738 p.

61. Hassell MP (1976) The dynamics of competition and predation. London, GB The Institute of Biology's studies in biology no.72. Edward Arnold Publishers. 68

62. Hero JM, Magnusson WE, Rocha CFD, Catterall CP (2001) Antipredator defenses influence the distribution of amphibian prey species in the Central Amazon rain forest. Biotropica 33: 131-141.

63. Hayes MP (1983) Predation on the adults and prehatching stages of Glass Frogs Centrolenidae). Biotropica 15: 74-76.

64. Warkentin KM (2005) How do embryos assess risk? Vibrational cues in predator-induced hatching of red-eyed treefrogs. Animal Behaviour 70: 59-71.

65. Ortega Andrade HM, Tobar C, Arellano M (2011) Tamaño poblacional, uso de hábitat y relaciones interespecíficas de Agalychnis spurrelli (Anura: Hylidae) en un 
bosque húmedo tropical remanente del noroccidente de Ecuador. Papéis Avulsos de Zoologia 51: 1-19.

66. Elmer KR, Cannatella D (2008) Three new species of leaflitter frogs from the upper Amazon forests: cryptic diversity within Pristimantis "ockendeni" (Anura: Strabomantidae) in Ecuador. Zootaxa 1784: 11-38.

67. McCracken S, Forstner M, Dixon JR (2007) A new species of the Eleutherodactylus lacrimosus assemblage (Anura, Brachycephalidae) from the lowland rainforest canopy of Yasuni National Park, Amazonian Ecuador. Phyllomedusa 6: 23-35.

68. Faivovich J, Moravec J, Cisneros-Heredia DF, Köhler J (2006) A new species of the Hypsiboas benitezi group from the Western Amazon basin (Amphibia: Anura: Hylidae). Herpetologica 62: 96-108.

69. Guayasamin JM, Ron S, Cisneros-Heredia DF, Lamar WE, McCracken S (2006) A new species of frog of the Eleutherodactylus lacrimosus assemblage (Leptodactylidae) from the western Amazon basin, with comments on the utility of canopy surveys in lownland rainforest. Herpetologica 62: 191-202.

70. Duellman WE, Mendelson J (1995) Amphibians and reptiles from northern Departamento Loreto, Peru: Taxonomy and biogeography. The University of Kansas Science Bulletin 55: 329-376.

71. Cisneros-Heredia DF, Reynolds RP (2007) New records of Phyllonastes Heyer, 1977 from Ecuador and Peru. Herpetozoa 19: 184

72. Ortega-Andrade HM (2009) Amphibia, Anura, Eleutherodactylidae, Adelophryne adiastola Hoogmoed and Lescure, 1984: First countries records and distribution extension from Ecuador and Brazil. Check List 5: 139-143.

73. Cisneros-Heredia D, Armijos-Ojeda D, Valarezo K (2009) First country record of Pristimantis metabates (Duellman and Pramuk) and distribution extension of Pristimantis skydmainos (Flores and Rodríguez) in eastern Ecuador (Amphibia, Anura, Strabomantidae). Herpetology Notes 2: 185-188.

74. Ortega-Andrade HM, Valencia J (2010) First country records of Pristimantis luscombei (Duellman and Mendelson) and Syncope tridactyla (Duellman and Mendelson) in eastern lowlands of Ecuador (Amphibia: Anura: Strabomantidae, Microhylidae). Herpetology Notes 3: 251-256.

75. Vigle GO (2008) The amphibians and reptiles of the Estación Biológica Jatun Sacha in the lowland rainforest of Amazonian Ecuador: A 20-year record. Breviora 514: 1-30.

76. Peterson A, Ball L, Cohoon K (2002) Predicting distributions of Mexican birds using ecological niche modelling methods. Ibis 144: 27-32.

77. Ochoa-Ochoa L, Urbina-Cardona N, Vázquez L, Flores-Villela O, BezauryCreel J (2009) The effects of governmental protected areas and social initiatives for land protection on the conservation of Mexican amphibians. PLoS One 4: e6878.

78. Pineda E, Lobo JM (2009) Assessing the accuracy of species distribution models to predict amphibian species richness patterns. Journal of Animal Ecology 78: $182-190$.

79. Wisz M, Hijmans R, Li J, Peterson A, Graham C, et al. (2008) Effects of sample size on the performance of species distribution models. Diversity and Distributions 14: 763-773.

80. Raxworthy C, Martinez-Meyer E, Horning N, Nussbaum R, Schneider G, et al. (2003) Predicting distributions of known and unknown reptile species in Madagascar. Nature 426: 837-841.
81. Elith J, Graham C, Anderson R, Dudik M, Ferrier S, et al. (2006) Novel methods improve prediction of species' distributions from occurrence data. Ecography 29: 129.

82. MAE (2005) Plan de Manejo y gestión participatica de la Reserva Ecológica Mache Chindul 2005-2010. Ecuador: Ministerio del Ambiente. 168 p.

83. MAE (2007) Plan de Manejo de la Reserva Ecológica Cotacachi Cayapas. Quito: Proyecto GEF Ecuador: Sistema Nacional de Áreas Protegidas (SNAPGEF). 269 p.

84. Alves DS, Morton DC, Bastistella M, Roberts DA, Souza C (2009) The changing rates and patterns of deforestation and land use in Brazilian Amazonia. In: Keller M, Bustamante M, Gash J, Silva Dias P, editors. Amazonia and Global Change Geophysical Monograph Series 186. Washington, D.C.: American Geophysical Union. pp. 11-23.

85. Dickinson RE, Henderson-Sellers A (1988) Modelling tropical deforestation: A study of GCM land-surface parametrizations. Quarterly Journal of the Royal Meteorological Society 114: 439-462.

86. Shukla J, Nobre C, Sellers P (1990) Amazon deforestation and climate change. Science 247: 1322

87. Vallan D (2002) Effects of Anthropogenic Environmental Changes on Amphibian Diversity in the Rain Forests of Eastern Madagascar. Journal of Tropical Ecology 18: 725-742.

88. Dodson CH, Gentry AH (1991) Biological extinction in western Ecuador. Annals of the Missouri Botanical Garden 78: 273-295.

89. FAO (2011) Situación de los bosques del mundo. Roma: Organización de las Naciones Unidas para la Agricultura y la Alimentación. 176 p.

90. Minda-Batallas PA (2002) Identidad y conflicto: La lucha por la tierra en la zona norte de la provincia de Esmeraldas. Quito, Ecuador: Abya-Yala y Escuela de Antropología Aplicada de la Universidad Politécnica Salesiana.

91. Sierra R (1996) La deforestación del noroccidente del Ecuador, 1983-1993. EcoCiencia. Quito, Ecuador. 20 p.

92. Cisneros-Heredia DF (2008) Habitat loss and climate change impacts on Neotropical anurans: Implications for in-situ conservation. A case study with Glassfrogs from eastern Ecuador (Amphibia: Anura: Centrolenidae). London: M.Sc. Dissertation. King's College. 73 p.

93. Guayasamin JM (2006) IUGN Red List of Threatened Species: Cochranella mache. $3.1 \mathrm{ed}$.

94. Sierra R, editor (1999) Propuesta preliminar de un Sistema de Clasificación de Vegetación para el Ecuador Continental. Quito-Ecuador: Proyecto INEFAN/ GEF-BIRF y EcoCiencia. 55-73 p.

95. Josse C (2001) La biodiversidad del Ecuador. Informe 2000. Quito: Ministerio del Medio Ambiente, EcoCiencia y UICN. 368 p.

96. Jatun-Sacha CDC-Ecuador (2002) Mapa de Cobertura Vegetal y Uso del Suelo del Ecuador. 1 ed. Azuay, Ecuador: Alianza Jatun Sacha (CDC-Ecuador).

97. Cisneros-Heredia DF, Guayasamin JM, McDiarmid RW (2006) Declining populations of Ecuadorian Glassfrogs (Centrolenidae). New Orleans, USA: Abstracts 2006 Joint Meeting of Ichthyologist and Herpetologists.

98. Cisneros-Heredia DF (2006) Review of the taxonomy and conservation status of the Ecuadorian Glassfrog Centrolenella puyoensis Flores \& McDiarmid (Amphibia: Anura: Centrolenidae). Zootaxa 2006: 21-31. 